\title{
Pre-Collision Automatic Braking System
}

\author{
Widha Bagus Fahriansyah \\ Mahasiswa Program Studi Mesin Otomotif, \\ Fakultas Teknik, Universitas Muhammadiyah Magelang \\ Email: widhabagusf@gmail.com
}

\section{Ringkasan}

Sistem Pre-Collision Automatic Braking System (PCABS) adalah sistem pengereman otomatis sebelum terjadinya tabrakan. Sistem ini bekerja dengan berbagai macam cara, ada yang menggunakan bantuan radar, memakai sensor, dan lain sebagainya. Sistem ini memiliki berbagai manfaat utama, yaitu membantu para pengendara untuk menghindari kecelakaan yang akan terjadi ataupun jika memang kecelakaan sudah tidak dapat dihindari maka bisa meminimalisir kerusakan yang terjadi pada pengendara maupun pada kendaraannya.

\section{Pendahuluan}

Seiring dengan pertumbuhan penduduk, jumlah pengendara khususnya mobil terus meningkat. Hal ini menyebabkan angka kecelakaan lalu lintas terus bertambah. Polri merilis data kecelakaan lalu lintas yang terjadi di Indonesia dalam 5 tahun terakhir, secara jumlah lebih banyak naik ketimbang turun. Secara detail, jumlah kecelakaan lalu lintas pada tahun 2014 mencapai 88.897 kejadian. Selanjutnya pada tahun 2015 naik menjadi 96.073, naik lagi di tahun 2016 menjadi 106.591 dan turun ke 104.327 di tahun 2017, kemudian naik lagi di tahun 2018 dengan jumlah 107.968 kejadian [1]. Saat ini, keselamatan berkendara menjadi issue utama dalam pengembangan mobil. Mulai dari sistem kontrol mekanikal sampai dengan kontrol elektronik [2].

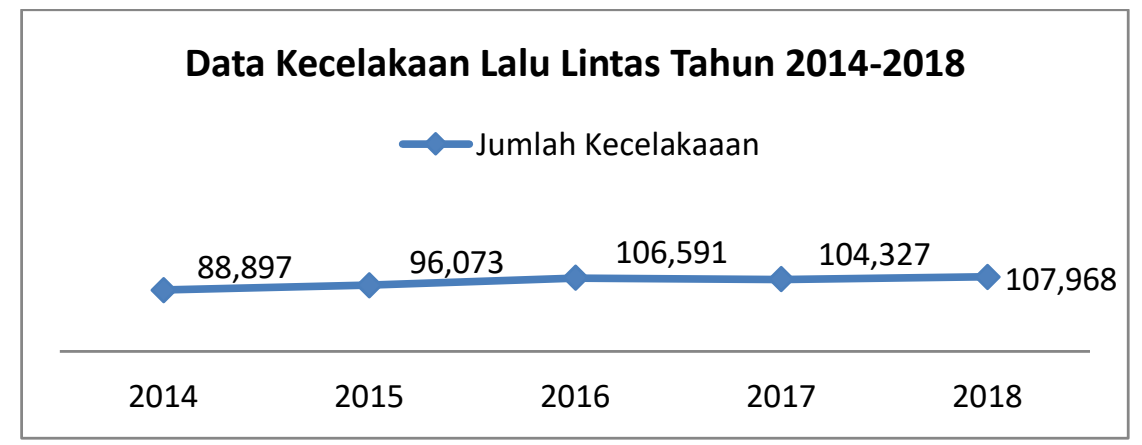

Gambar 1. Data kecelakaan lalu lintas tahun 2014-2019 [1]

Dalam hal ini untuk membantu pemerintah dalam upaya mengurangi angka kecelakaan lalu lintas, di artikel ini saya akan memperkenalkan teknologi yang bernama sistem pratabrakan pengereman otomatis. Teknologi ini adalah sebuah sistem keamanan mobil yang 
dibuat untuk mengurangi risiko kecelakaan. Sistem ini memakai bantuan radar dan kadang juga menggunakan sensor laser untuk mendeteksi adanya kemungkinan tabrakan. Sistem ini bekerja dengan berbagai macam cara, misalnya dengan mengingatkan si pengendara melalui voice, mengubah posisi tempat duduk, mengubah posisi bantalan kepala (head rest), mengencangkan sabuk pengaman (seat belt), dan pengereman otomatis [3].

\section{Sistem Pre-Collision Automatic Braking System (PCABS)}

Sistem Pre-Collision Automatic Braking System menggunakan radar untuk memonitor situasi di depan dan sistem akan mengerem mobil secara otomatis dan mengencangkan sabuk pengaman jika pengendara tidak mempedulikan peringatan audio yang diberikan oleh panel instrumen. PCABS menggunakan radar gelombang milimeter untuk mendeteksi kendaraan di depan dalam jarak 100 meter, dan kemudian menghitung jarak antara kendaraan, kecepatan kendaraan relatif, dan jalur kendaraan yang diantisipasi untuk menentukan kemungkinan tabrakan. Jika sistem menentukan bahwa kemungkinan tabrakan, itu terdengar bel dan memberikan peringatan audio, mengencangkan sabuk pengaman untuk mendorong pengemudi untuk mengambil tindakan pencegahan. Sistem ini juga menggabungkan sejumlah fungsi untuk mengurangi benturan pada penghuni jika benturan tidak dapat dihindari, termasuk fungsi bantu rem yang mengkompensasi tekanan pedal yang tidak mencukupi untuk mengurangi kecepatan benturan dan kontrol sabuk pengaman yang meningkatkan ketegangan sabuk pengaman untuk menahan pengemudi lebih aman di tempatnya [4].

\section{Cara Kerja}

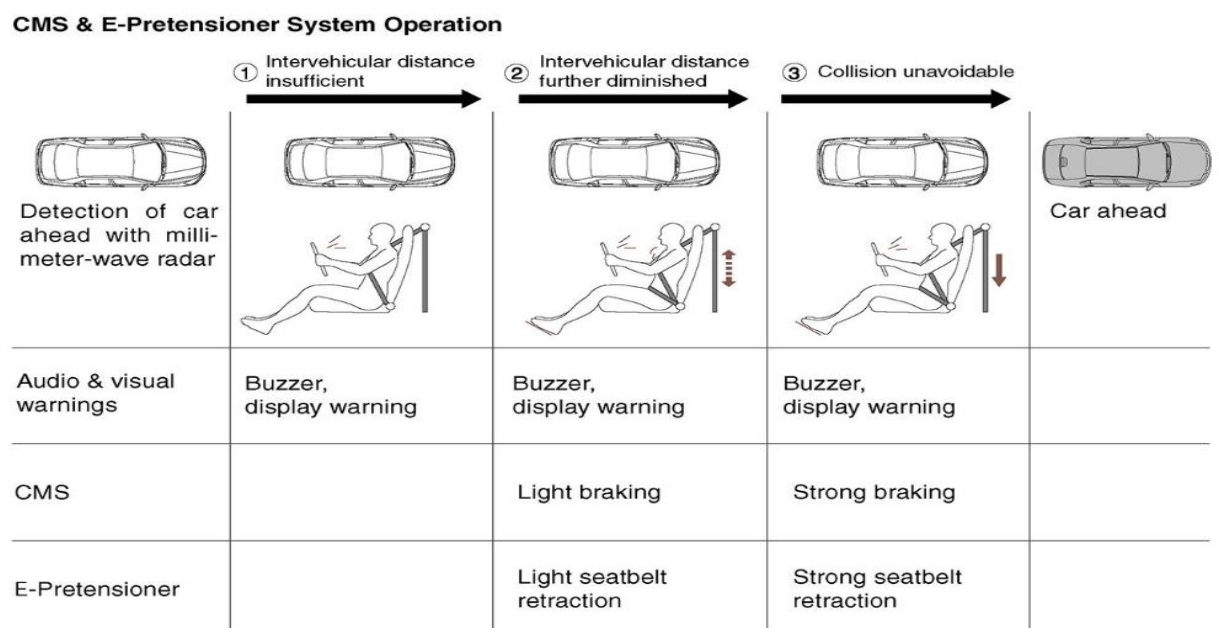

Gambar 2. CMS \& E-Pretensioner System Operation [4]

Cara kerja sistem PCABS ini terbagi menjadi 3 tahap: 
1. Peringatan pertama

Ketika ada risiko tabrakan dengan kendaraan di depan atau jika jarak antara kendaraan menjadi terlalu pendek, maka alarm akan berbunyi, dan pesan "BRAKE" muncul pada tampilan multi-informasi di panel instrumen, hal itu akan mendorong pengemudi untuk mengambil tindakan pencegahan.

2. Peringatan kedua

Jika jarak antara kedua kendaraan terlalu dekat dan tidak dapat dihindari, CMS menerapkan pengereman ringan, dan E-Pretensioner akan menarik sabuk pengaman dengan lembut dua atau tiga kali, kemudian memberi pengemudi peringatan taktil. Pada titik ini, jika pengemudi menggunakan rem, sistem mengartikan tindakan ini sebagai rem darurat, dan mengaktifkan fungsi bantuan rem untuk mengurangi kecepatan tabrakan atau pengurangan kerusakan.

3. Peringatan terakhir

Jika sistem menentukan bahwa tabrakan tidak dapat dihindari, sistem E-Pretensioner akan menarik sabuk pengaman dengan kekuatan yang cukup untuk mengompensasi sabuk pengaman atau longgar, memberikan retensi pengemudi yang lebih efektif daripada pretensioner sabuk pengaman konvensional, yang hanya mulai beroperasi setelah tabrakan terjadi . CMS juga mengaktifkan rem secara paksa untuk mengurangi kecepatan tabrakan. E-Pretensioner dirancang untuk beroperasi kapan pun pengemudi mengerem secara tiba-tiba dan fungsi rem membantu mengencangkan sabuk pengaman untuk mengamankan pengemudi.

\section{Komponen sistem CMS dan E-Pretensioner}

1. Radar gelombang milimeter Mendeteksi kendaraan dalam jarak sekitar 100 meter di depan, dalam lengkungan 16 derajat.

2. Sensor

Sistem menentukan kondisi mengemudi menggunakan berbagai sensor yang mendeteksi faktor-faktor seperti kecepatan menguap, sudut kemudi, kecepatan roda, dan tekanan rem.

3. Unit Kontrol Elektronik CMS (ECU) 
Berdasarkan jarak ke kendaraan di depan dan kecepatan relatif yang diperoleh dari informasi radar, dan pada jalur kendaraan yang diantisipasi sebagaimana ditentukan berdasarkan informasi sensor, ECU menghitung kemungkinan tabrakan, dan memperingatkan pengemudi, dan dalam beberapa kasus mengaktifkan fungsi pengereman . ECU bertukar informasi sesuai kebutuhan dengan E-Pretensioner, Variable Signal Analyzer (VSA) dan Meter Unit.

4. Unit hidrolik terintegrasi SA-ECU

Menerima informasi dari berbagai sensor, dan mengirimkan informasi ini ke CMS ECU dan unit kontrol lainnya. Juga mengontrol unit hidrolik rem untuk mengaktifkan rem berdasarkan instruksi dari CMS ECU.

\section{E-Pretensioner ECU}

Mengirim instruksi ke E-Pretensioner bermotor untuk menarik sabuk pengaman, berdasarkan sinyal instruksi pengereman dari CMS ECU dan sinyal bantuan rem yang dikendalikan secara elektronik.

6. E-pretensioner

Tarik sabuk pengaman menggunakan motor internal, berdasarkan instruksi dari EPretensioner ECU. Digunakan dalam kombinasi dengan pretensioner konvensional.

7. Unit meteran

Menerima sinyal dari CMS ECU, dan memperingatkan pengemudi tentang potensi bahaya menggunakan bel dan peringatan visual

CMS \& E-Pretensioner System Overview

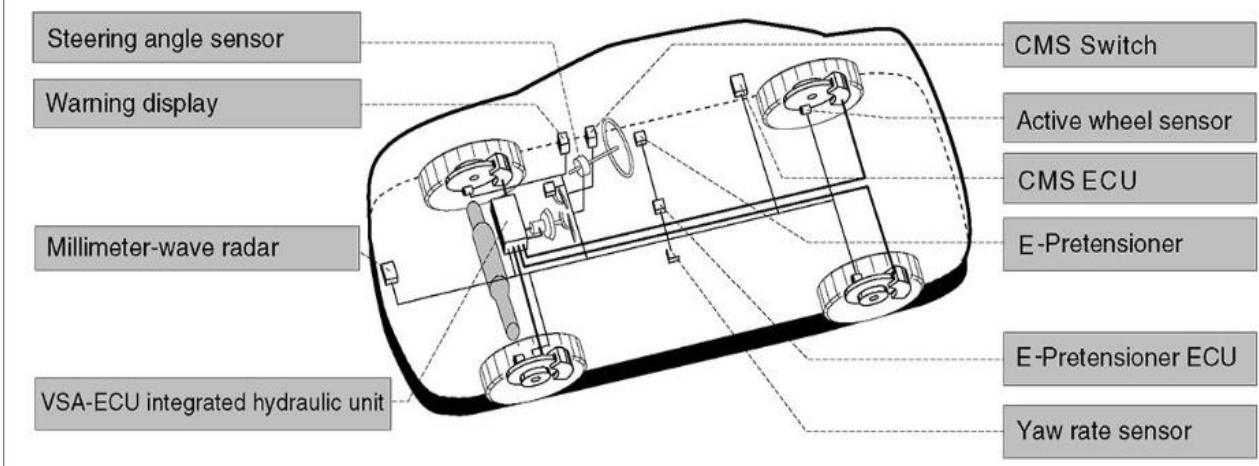

Gambar 2. CMS \& E-Pretensioner System [4] 


\section{Perkembangan PCABS}

Sistem PCABS ini pertama kali di coba pada awal tahun 1950-an, contohnya pada cadillac yang mengembangkan kendaraan prototipe bernama cadillac cyclone yang menggunakan teknologi radar baru untuk mendeteksi objek di dpean mobil dengan sensor radar yang dipasang didalam kerucut hidung [5]. Kemudian sistem modern menghindari tabrakan ke depan modern ditunjukkan pada tahun 1995 oleh tim ilmuwan dari insinyur di laboratorium penelitian hughes di malibu, California. Kemudian teknologi ini dipasarkan sebagai prakata, sistem ini berbasis radar teknologi yang tersedia di hughes elektronik, tetapi tidak secara komersial ditempat lain. Sistem ini menggunakan antena radar pabrikasi kecil yang dibuat khusus dan dikembangkan khusus untuk aplikasi otomotif pada 77 Ghz. Pada agustus 1997, produksi cruise control adaptif laser pertama pada kendaraan toyota diperkenalkan pada model celsior.

Sebagai bagian dari upaya memastikan keselamatan berkendara di jalan, Toyota Motor Corporation baru saja mengumumkan sistem pengereman otomatis baru yang melibatkan teknologi GPS (Global Positioning System) canggih untuk pemantauan posisi yang akurat agar sistem pengereman kendaraan bekerja secara otomatis. Ini akan mengenali tanda-tanda berhenti di persimpangan dan kemudian memperingatkan pengendara dengan peringatan suara dan visual dan akhirnya menerapkan daya rem yang cukup untuk menghindari tabrakan atau mengurangi dampak kerusakan yang terjadi. Mekanisme sistem ini menggunakan pengindaraan koordinat yang cerdas dan akurat mengguanakan sistem GPS dengan bantuan modul kamera yang dipasang dibagian belakang mobil.

Ketika kendaraan berada pada jarak 100 meter dari tanda berhenti, kamera yang dipasang di belakang akan mulai mendeteksi tanda-tanda berhenti awal di jalan dan kemudian memberitahu pengemudi melalui alarm lembut yang dapat didengar . ketika kendaraan mendekati, sekitar empat detik sebelum tanda berhenti, sistem rem otomatis akan diaktifkan untuk melanjutkan pemantuan jika pengemudi memiliki niat untuk menghentikan kendaraan dan jika tidak, kekuatan tambahan akan diterapkan untuk lebih memperlambat kendaraan secara otomatis, kemudian sistem pengereman dihubungkan kembali ke GPS untuk kalibrasi lokasi yang akurat dengan pemantuan waktu nyata [6].

\section{Kesimpulan}

Sistem Pre-Collision Automatic Braking System memiliki manfaat utama salah satunya adalah dapat mendeteksi kemungkinan tabrakan atau bisa mengurangi kerusakan yang terjadi baik pada kendaraan maupun pengendaranya. Sistem ini juga memberikan pengaruh yang 
sangat besar pada angka kecelakaan karna dengan hadirnya sistem ini angka kecelakaan bisa dikurangi dan kerugian material bagi pihak produksi mobil maupun pada pengendaranya sendiri bisa diminimalkan, dan juga bisa membuat pengendara khususnya mobil bisa lebih aman, dan nyaman dalam berkendara.

\section{Referensi}

[1] A. Maulana, "Jumlah Korban Kecelakaan Lalu Lintas di Indonesia Harus Turun," 2019. .

[2] H. Fahrian, S. Munahar, and D. S. Putra, "Pengembangan Sirkuit Security System untuk Meningkatkan Driver Behavior Control pada Kendaraan," Automotive Experiences, vol. 1, no. 1, pp. 13-19, 2018.

[3] Wikipedia, "sistem pratabrakan." .

[4] Honda, "Honda Develops World's First 'Collision Mitigation Brake System'(CMS) for Predicting Rear-end Collisions and Controlling Brake Operations," 2003. .

[5] InternetArchiveBot, "cadillac cyclone," 2019. .

[6] S. Wong, "Toyota Mengembangkan Sistem Rem Otomatis yang Dibantu dengan Teknologi GPS untuk Keselamatan Berkendara.”. 